precipitates no longer takes up its space on the resin.

Because of the difference in behaviour of the acetic acid and hydrochloric acid extracts when subjected to the same chromatographic procedure it seems safe to conclude that they differ chemically. This is further borne out by the difference in their stability in various buffer systems, and their electrophoretic properties (Dr H. Rasmussen, unpublished work). For sake of reference, we have called the active material extracted by hydrochloric acid, Parathormone A (PTH-A) and that extracted by acetic acid, Parathormone B (PTH-B).

\section{SUMMARY}

1. A method is described for the partial purification of parathyroid hormone by means of hydrochloric acid extraction, acetone fractionation, ultrafiltration and displacement chromatography on ion-exchange resin.

2. The procedure yields material of potency 75100 units/mg. dry weight (500-700 units/mg. of $N$ ) in quantities of $90-100 \mathrm{mg} \cdot / 600 \mathrm{~g}$. of fresh bovine glands.

3. This material is heterogeneous on electrophoresis at pH $\mathbf{2 \cdot 5}$.

4. Evidence is presented which suggests that the active material obtained by means of acetic acid and hydrochloric acid extraction respectively have different chemical properties.

We wish to thank Dr A. H. Gordon for his constant interest and many helpful suggestions. Our thanks also to Professor C. E. Dent and Professor M. Rosenheim for their support of, and interest in, this work, which was initiated at their suggestion. This work was supported in part by grant A-1331 of the U.S. Public Health Service, and was carried out while one of us (H.R.) was a recipient of a U.S. Public Health Research Fellowship.

\section{REFERENCES}

Collip, J. B. (1925). J. biol. Chem. 63, 395.

Craig, L. C. \& King, T.P.(1955). J.Amer.chem. Soc.77, 6620.

Davies, B. M. A. \& Gordon, A.H. (1955). Biochem. J.61, 646.

Davies, B. M. A., Gordon, A. H. \& Mussett, M. V. (1954). J. Physiol. 125, 383.

Davies, B. M. A., Gordon, A. H. \& Mussett, M. V. (1955). J. Physiol. 130, 79.

Dyer, F. J. (1935). Quart. J. Pharm. 8, 197.

Greep, R. O. (1948). Physiology and Chemistry of Parathyroid Hormone. In The Hormones, vol. 1, ed. by Pincus, G. \& Thimann, K. V. New York: Academic Press Inc.

Greep, R. O. \& Kenny, A. D. (1955). Physiology and Chemistry of the Parathyroids. In The Hormones, vol. 3, ed. by Pincus, G. \& Thimann, K. V. New York: Academic Press Inc.

Handler, P., Cohn, D. V. \& Dratz, A. F. (1954). Studies on the Purification of Parathyroid Extract. In Metabolic Interrelations with Special Reference to Calcium. Trans. 5th Josiah Macy Conf. p. 320. New York: Progress Associated Inc.

Hanson, A. M. (1925). Proc. Soc. exp. Biol., N.Y., $22,560$.

Kenny, A. D. \& Toverud, S. U. (1954). Analyt. Chem. 26, 1059.

L'Heureux, M. V., Tepperman, H. M. \& Wilhelmi, A. E. (1947). J. biol. Chem. 168, 167.

Moussu, G. (1898). C.R. Soc. Biol., Paris, 5, 867.

Raoul, M. Y., Marnay, C. \& Prelot, M. (1955). C.R. Acad. Sci., Paris, 240, 1151.

Rasmussen, H. \& Westall, R. G. (1956). Nature, Lond., 178, 1173.

Rasmussen, H. \& Westall, R. G. (1957). Nature, Lond. (in the Press).

Ross, W. F. \& Wood, T. R. (1942). J. biol. Chem. 146, 49.

Tepperman, H. M., L'Heureux, M. V. \& Wilhelmi, A. E. 1947). J. biol. Chem. 168, 151.

\title{
The Structure of Serratamic Acid
}

\author{
By N. J. CARTWRIGHT \\ Department of Bacteriology, University of Birmingham
}

(Received 22 May 1957)

In a previous communication (Cartwright, 1955) the isolation of serratamic acid, a metabolic product of organisms of the Serratia group, was described. On the basis of the nature of its hydrolytic products and lack of ninhydrin reaction a peptide structure was advanced and this has now been confirmed by synthesis. In particular, L-serine was rigidly established as a product of acidic hydrolysis. Both alkaline and acidic hydrolysis yielded an acid,
$\mathrm{C}_{10} \mathrm{H}_{20} \mathrm{O}_{3}$, which was tentatively equated with a hydroxydecanoic acid, and has now been identified as D-3-hydroxydecanoic acid.

\section{Molecular formula of serratamic acid}

Earlier experiments favoured a molecular formula $\mathrm{C}_{13} \mathrm{H}_{25} \mathrm{O}_{5} \mathrm{~N}$ for serratamic acid but did not entirely exclude the possibility of its being a larger molecule. Subsequently serratamic acid has been converted 
into serratamic acid methyl ester, $\mathrm{C}_{14} \mathrm{H}_{27} \mathrm{O}_{5} \mathrm{~N}$, by the action of diazomethane on an ethereal suspension of the acid or by the action of methyl iodide on a methanolic suspension of the silver salt of the acid. The stability of this ester in molten camphor has enabled molecular-weight determinations to be done by the Rast method, when values in accordance with $\mathrm{C}_{14} \mathrm{H}_{27} \mathrm{O}_{5} \mathrm{~N}$ were consistently obtained. This evidence, together with the previously reported equivalent weight, and the failure of further attempts to isolate other fragments from hydrolysates is regarded as proof that the serratamic acid molecule is represented by $\mathrm{C}_{13} \mathrm{H}_{25} \mathrm{O}_{5} \mathrm{~N}$.

\section{Identification of the $\mathrm{C}_{10}$ acid}

Doubts about the structure of the carbon chain of the $\mathrm{C}_{10}$ degradation acid (Cartwright, 1955) were resolved in two ways. Branched-chain structures were eliminated by $C$-methyl determinations, which gave negative results. The presence of a $n-\mathrm{C}_{10}$ chain was confirmed by treatment of the acid with phos- phoryl chloride or phosphorus pentoxide in benzene followed by catalytic reduction of the unsaturated or chlorinated product, or both; decanoic acid was thus obtained and its identity established by preparation and analysis of the anilide and $p$-bromophenacyl ester, which were also compared with the corresponding derivatives of authentic decanoic acid.

When larger quantities of serratamic acid were available a more rigorous purification of the $\mathrm{C}_{10}$ degradation acid was made. After vacuum distillation the acid was crystallized at low temperature from light petroleum, forming felted needles, m.p. $47^{\circ}$. A direct oxygen determination confirmed the formula $\mathrm{C}_{10} \mathrm{H}_{20} \mathrm{O}_{3}$ previously allotted. Small quantities of impurity caused the substance to separate from solvents in a form only filterable with difficulty. The pure substance showed minor changes in infrared spectrum (Fig. 1) and the resemblance of the absorption to that of DL-3-hydroxydecanoic acid (Fig. 2) was more pronounced, the minor differences

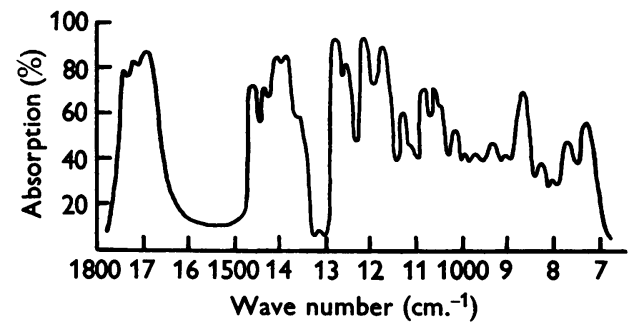

Fig. 1

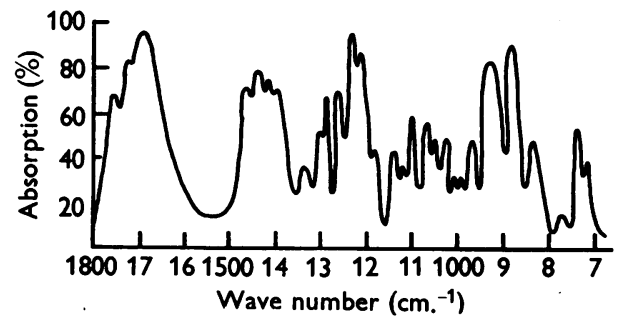

Fig. 2

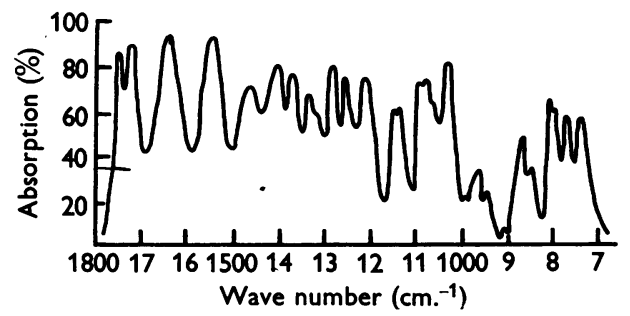

Fig. 3

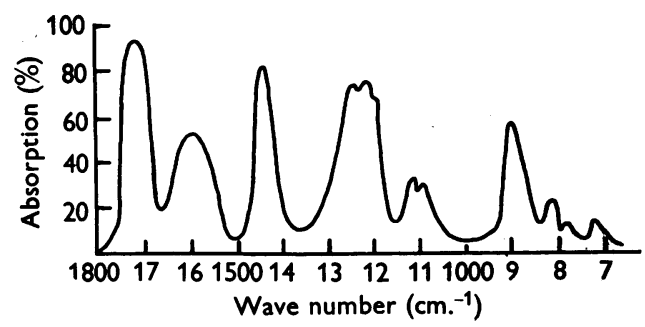

Fig. 4

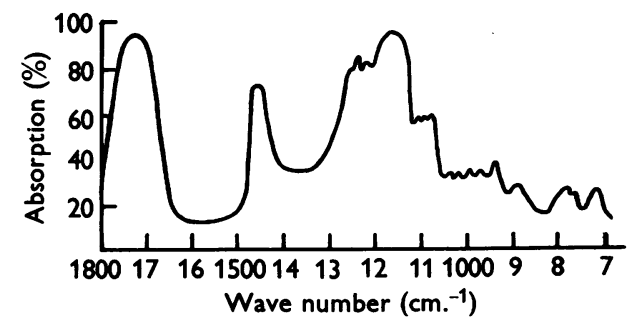

Fig. 5

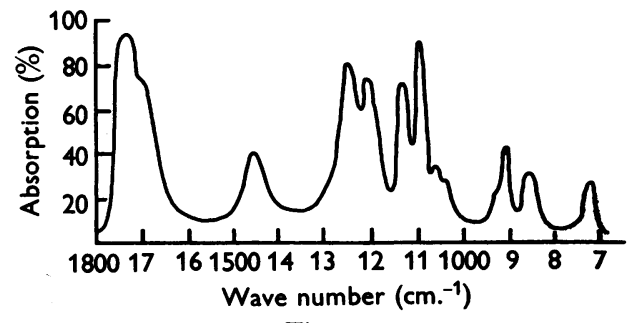

Fig. 6

Infrared spectra. Fig. 1. The acid $\mathrm{C}_{10} \mathrm{H}_{20} \mathrm{O}_{3}$ from serratamic acid (2.2 mg./cm. ${ }^{2}$ in $\left.\mathrm{KBr}\right)$. Fig. 2. DL-3-Hydroxydecanoic acid $\left(1.4 \mathrm{mg} \cdot / \mathrm{cm}^{2}\right.$ in $\left.\mathrm{KBr}\right)$. Fig. 3. Serratamic acid $\left(2 \cdot 8 \mathrm{mg} . / \mathrm{cm} . .^{2}\right.$ in $\left.\mathrm{KBr}\right)$. Fig. 4. 2:3-Epoxydecanoic acid (1.5 mg./cm.2 in $\mathrm{KBr})$. Fig. 5. 2-Hydroxy-2-methylnonanoic acid (1.5 mg./cm. ${ }^{2}$ in $\left.\mathrm{KBr}\right)$. Fig. 6. 2-Hydroxydecanoic acid $\left(0.6 \mathrm{mg} . / \mathrm{cm} .^{2}\right.$ in $\mathrm{KBr}$.) 
being no greater than might reasonably be attributed to optical configuration. Accordingly, the optical properties of the acid were re-examined. No measurable rotation was observed in ethanol solution, but in chloroform activity was demonstrated, the acid having $[\alpha]_{\mathrm{D}}^{20}-19 \pm 1^{\circ}(c, 2 \cdot 1)$. By a tedious fractional crystallization of the cinchonidine salts of DL-3-hydroxydecanoic acid (the configurations of which are deduced from evidence presented below) the enantiomorphic forms were obtained. The less soluble cinchonidine salt was that of D-3-hydroxydecanoic acid, having m.p. $119^{\circ}$, $[\alpha]_{\mathrm{D}}^{20}-82 \cdot 5 \pm 0 \cdot 5^{\circ}$ in chloroform $(c, 2 \cdot 0)$, yielding an acid having m.p. $47^{\circ},[\alpha]_{D}^{20}-17 \cdot 5 \pm 2^{\circ}$ in chloroform $(c, 0.9)$. The more soluble cinchonidine salt was that of L-3-hydroxydecanoic acid, m.p. $98^{\circ},[\alpha]_{\mathrm{D}}^{20}-67 \pm$ $0.5^{\circ}$ in chloroform $(c, 1 \cdot 27)$. It gave an acid, m.p. $46^{\circ},[\alpha]_{\mathrm{D}}^{20}+18 \pm 2^{\circ}$ in chloroform $(c, 0 \cdot 9)$. A mixture of equal parts of the antipodes melted at $57^{\circ}$. Admixture of the degradation acid with the laevorotatory form gave no depression in melting point, whereas admixture with an equal weight of the dextrorotatory form gave m.p. $57^{\circ}$. The latter mixture did not depress the melting point of $\mathrm{DL}-3$ hydroxydecanoic acid. The antipodes of 3-hydroxydecanoic acid are more soluble in petroleum than is the racemic acid. With the small quantities available the rotation of the antipodes in ethanol solution did not exceed the possible experimental error of $\pm 2^{\circ}$.

Subsequent to this study Serck-Hanssen \& Stenhagen (1955) and Serck-Hanssen (1956) published a synthesis of L-3-hydroxydecanoic acid having $[\alpha]_{D}^{22}+20^{\circ}$ in chloroform and $-3^{\circ}$ in ethanol, starting from precursors of known absolute configuration. This substance was shown to be the antipode of an acid isolated from natural sources by Bergström, Theorell \& Davide (1946).

Through the courtesy of Dr Serck-Hanssen, observations were made on the mixed-meltingpoint behaviour of his acid with the antipodes from DL-3-hydroxydecanoic acid and the acid obtained fromserratamic acid. Bothlaevorotatory 3-hydroxydecanoic acid and the degradation acid, when mixed separately with equal weights of Serck-Hanssen's acid, showed m.p. $57^{\circ}$, the mixture not depressing the melting point of authentic DL-3-hydroxydecanoic acid. There was also no depression in mixtures of the resolved dextrorotatory substance and SerckHarissen's dextrorotatory form. These observations, supported by a comparison of infrared spectra, including that of L-3-hydroxydecanoic acid, a copy of which was supplied by Dr Serck-Hanssen, show that the hydrolytic product $\mathrm{C}_{10} \mathrm{H}_{20} \mathrm{O}_{3}$ is D-3-hydroxydecanoic acid and that serratamic acid provides another example of a naturally occurring derivative of this acid.

The $p$-bromophenacyl ester of D-3-hydroxydecanoic acid (from the resolved acid), m.p. $105^{\circ}$, exhibited no depression in melting point on admixture with the previously reported derivative of the degradation acid, and they were identical in solubility and crystal habit. It follows that the methyl ester obtained from treatment with methanolic hydrogen chloride of serratamic acid is methyl D-3-hydroxydecanoate (m.p. $13^{\circ},[\alpha]_{\mathbf{D}}^{20}-$ $18 \cdot 3 \pm 1^{\circ}$ in chloroform $\left.c, 2 \cdot 75\right)$. The presence of the hydroxyl group was chemically confirmed by conversion of the ester into the liquid methyl D-3acetoxydecanoate, b.p. $73^{\circ} / 0.07 \mathrm{~mm}$., by the action of cold acetic anhydride. The methyl ester showed no tendency to cyclic-ester formation (see below). Attempts to prepare substituted $O$-benzoyl derivatives gave either unchanged material or unsaturated compounds, the latter being also found in some experiments with the free acid. From aqueous acid hydrolysis of serratamic acid and the action of mineral acids on, and attempts at acylation on, the $\mathrm{C}_{10}$ acid there was always obtained a neutral oily fraction which by alkaline hydrolysis gave almost theoretical yields of the $\mathrm{C}_{10}$ acid.

On the basis of boiling point, analytical figures and hydrolysis it must be concluded that this lactone-like substance is the cyclic ester, $\mathrm{C}_{20} \mathrm{H}_{36} \mathrm{O}_{4}$ (I).

\section{Structure and synthesis of serratamic acid}

The observations of this and the earlier communication lead to the conclusion that serratamic acid is $N$-(D-3-hydroxydecanoyl)-L-serine

$$
\text { (II; } \mathrm{R}^{\mathbf{1}}=\mathrm{R}^{\mathbf{2}}=\mathrm{H} \text { ). }
$$

and in support of this its infrared spectrum (Fig. 3) shows absorption at 1649 and $1632 \mathrm{~cm} .^{-1}$, attributable to the $=\mathrm{CO}$ of a secondary amide, and at $1549 \mathrm{~cm} \cdot{ }^{-1}$, attributable to the $=\mathrm{NH}$ of a secondary amide.

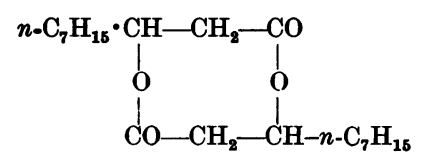

(I)

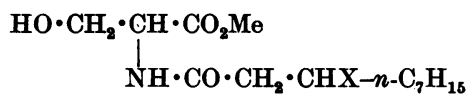

(III)

$$
\mathrm{R}^{1} \mathrm{O} \cdot \mathrm{CH}_{2} \cdot \underset{\mathrm{NH}}{\mathrm{CH}} \cdot \mathrm{CO} \cdot \mathrm{CO}_{2} \mathrm{H}
$$

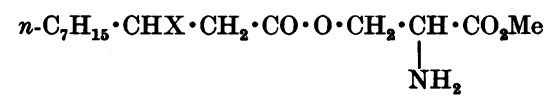

(IV) 
The possible synthetic routes to serratamic acid were limited by observations of the difficulty in isolating pure derivatives of the general type (II) ( $R^{1}$ and $R^{2}=a c y l$, alkyl, arylalkyl) from serratamic acid itself and the problems which could arise from the lability of the molecule in attempts to regenerate serratamic acid from such derivatives. In the direct condensation of serine and an appropriate acid chloride both $O$ - and $N$-acylation can occur, and in order to limit $O$-acetylation by the desired acid chloride $O$-acetyl-DL-serine (Sakami \& Toennies, 1942) was prepared for model experiments. However, the insolubility of this substance in solvents inert to acid chlorides prevented the condensation. All attempts to esterify $O$-acetylserine or to acetylate serine methyl ester to produce a more soluble derivative failed, or resulted respectively in deacetylation or demethylation. Recourse was then made to the difference in properties of products of the type (III) and (IV) (X=halogen or acyloxy) which could arise by simultaneous $O$ - and $N$ acylation of serine methyl ester by the appropriate acid chloride, the desired $N$-acylated product (III) being insoluble in both dilute acid and alkali.

Because of the difficulty in preparing quantities of the synthetic optical isomers of the amino acid and hydroxy acid moieties of serratamic acid, model experiments were first carried out on the readily available DL-serine and DL-3-hydroxydecanoic acid. The action of thionyl chloride on DL3-hydroxydecanoic acid gave a predominance of chlorine-free product consistent with the cyclic ester (I). Although pure DL-3-acetoxydecanoic acid could not be prepared by the action of acetyl chloride and pyridine on the acid in the cold, the subsequent treatment of the crude product with thionyl chloride showed that some appreciable acetylation and formation of acid chloride had occurred because condensation of this second crude product with serine methyl ester gave a neutral nitrogenous fraction. By the action of cold dilute alkali this fraction lost acetyl and methyl ester groups and gave good yields of racemic serratamic acid or DL- $N$-(3-hydroxydecanoyl)serine, m.p. $144^{\circ}$.

By a similar condensation serratamic acid was synthesized by recombination of the L-serine and D-3-hydroxydecanoic acid moieties obtained directly from serratamic acid itself and by condensation of commercial L-serine and D-3-hydroxydecanoic acid obtained by resolution of DL-3-hydroxydecanoic acid in this Laboratory. The two synthetic products and natural serratamic acid had identical single and mixed melting points and were identical in solubility, crystal habit and optical properties.

There was left after distillation of the crude neutral fraction from treatment of serratamic acid with methanolic hydrogen chloride a residue which solidified and which on purification formed a neutral substance, m.p. 94 ${ }^{\circ}$, containing chlorine and methoxyl. Elementary analysis showed this to be $\mathrm{C}_{14} \mathrm{H}_{28} \mathrm{O}_{4} \mathrm{Cl}$, i.e. chloroserratamic acid methyl ester $(\mathrm{V} ; \mathrm{R}=\mathrm{Cl})$.

$$
\begin{aligned}
& \mathrm{R} \cdot \mathrm{CH}_{2} \cdot \mathrm{CH} \cdot \mathrm{CO}_{2} \mathrm{Me} \\
& \begin{array}{c}
\mathrm{NH} \cdot \mathrm{CH}_{2} \cdot \mathrm{CH}(\mathrm{OH})-n-\mathrm{C}_{7} \mathrm{H}_{15} \\
\mathrm{~N}_{2}(\mathrm{~V})
\end{array}
\end{aligned}
$$

The structure of this product was deduced by catalytic reduction, when the chlorine atom was removed to give deoxyserratamic acid methyl ester, m.p. $58^{\circ}(\mathrm{V} ; \mathrm{R}=\mathrm{H})$, which on hydrolysis with hydrochloric acid gave rise to $\alpha$-alanine, identified by paper chromatography, showing that the hydroxyl group of the serine moiety of serratamic acid had been replaced by chlorine. Attempts to prepare larger quantities of the chloro derivative by the action of thionyl chloride and phosphorus chlorides on serratamic acid methyl ester were accompanied by extensive decomposition. The action of hydrogen chloride in different solvents and conditions gave either unchanged material or Lserine and D-3-hydroxydecanoic acid.

\section{Properties of some oxygenated decanoic acids}

Owing to apparently confusing evidence obtained in earlier stages of this study, other oxygenated decanoic acids were prepared for comparison with the $C_{10}$ degradation acid.

2:3-Epoxydecanoic acid (infrared spectrum, Fig. 4) was synthesized by a Claisen-Darzen-type condensation between octyl aldehyde and ethyl chloroacetate. This substance is capable of existence in cis and trans forms, but an attempt to prepare a geometrical isomer by oxygen-ring fission gave a chlorohydroxydecanoic acid, m.p. $93^{\circ}$, but only the original epoxy acid was regenerated on dehydrochlorination with ethanolic potassium hydroxide. Suitable conditions for the reduction of the chlorine atom in the molecule could not be found and hence the position of the substituents was not established. The action of per-acids on 2:3-decenoic acid failed to yield an epoxy acid.

2-Hydroxy-2-methylnonanoic acid (infrared spectrum, Fig. 5) was synthesized by a method similar to that of Maehlmann (1915). In contrast to the degradation acid this substance was readily converted into a $p$-nitrobenzoyl derivative, m.p. $137^{\circ}$.

2-Hydroxydecanoic acid was also prepared and its infrared spectrum (Fig. 6) determined.

\section{EXPERIMENTAL}

All melting points are uncorrected.

Serratamic acid methyl ester. This was prepared in two ways: (a) A solution of serratamic acid (2 g.) in methanol $\left(5 \mathrm{ml}\right.$.) was added to a solution of $\mathrm{AgNO}_{3}(1.24 \mathrm{~g}$.$) in$ 
methanol (50 ml.). After the addition of $\mathrm{K}_{2} \mathrm{CO}_{3}(0.5 \mathrm{~g}$.) in the minimum quantity of water the suspension of silver salt was refluxed with a large excess of methyl iodide for $18 \mathrm{hr}$. The solid was separated by filtration and the filtrate evaporated under reduced pressure, leaving an oil which solidified. After washing with saturated $\mathrm{NaHCO}_{3}$ solution and water to remove unchanged acid, the product was dried and crystallized from amyl ether from which $1.5 \mathrm{~g}$. of felted needles separated, m.p. $95^{\circ}$ (Found: C, 58.7; $\mathrm{H}, 9 \cdot 2 ; \mathrm{N}, 4 \cdot 6 . \mathrm{C}_{14} \mathrm{H}_{27} \mathrm{O}_{5} \mathrm{~N}$ requires $\mathrm{C}, 58 \cdot 2 ; \mathrm{H}, 9 \cdot 0 ; \mathrm{N}$, $4.8 \%$ ).

(b) A suspension of serratamic acid ( 2 g.) in dry ether (100 ml.) was treated in portions with a solution of diazomethane in dry ether until an excess of methylating agent was present, as judged by the yellow colour persisting for 5 min. The filtered solution was then evaporated and the product crystallized from amyl ether. This substance, m.p. 94-95 ${ }^{\circ}$, gave no depression in m.p. with that prepared as above.

Of several mixtures used in the Rast determination of mol.wt. the following is an example. The ester $(0.0514 \mathrm{~g}$.) was dissolved in camphor $(0.5013 \mathrm{~g}$.). The original camphor had m.p. $177 \cdot 5^{\circ}$, and the mixture, m.p. $163 \cdot 6^{\circ}, 164^{\circ}, 164^{\circ}$. The depression of $14^{\circ}$ corresponds to mol.wt. 291. $\mathrm{C}_{14} \mathrm{H}_{27} \mathrm{O}_{5} \mathrm{~N}$ requires 289.

Dehydration experiments on the degradation acid $\left(\mathrm{C}_{10} \mathrm{H}_{20} \mathrm{O}_{3}\right)$. (a) With phosphorus pentoxide. The acid $(1 \cdot 0 \mathrm{~g}),. \mathrm{P}_{2} \mathrm{O}_{5}(2 \mathrm{~g}$.) and dry benzene $(25 \mathrm{ml}$.) were heated under reflux for $30 \mathrm{~min}$. and, after cooling, water was cautiously added and the organic layer separated. An acidic fraction was removed from the benzene solution by extraction into saturated $\mathrm{NaHCO}_{3}$ solution, from which it was isolated as an oil $(0 \cdot 3 \mathrm{~g}$.) by acidification and extraction with ether followed by drying and removal of the solvent. This unsaturated substance was dissolved in methanol (5 ml.) and shaken with $\mathrm{Pd}$-charcoal catalyst $\left(10 \%, w / w ; 0.05\right.$ g.) in $\mathrm{H}_{2}$ at room temp. and pressure until the rapid absorption of $\mathrm{H}_{2}$ ceased; the catalyst was then removed and the solvent evaporated under reduced pressure, leaving an oil which was solid at low temperature. A small quantity was pressed on a porous tile to remove a trace of oil and gave a solid, m.p. 30-31 ${ }^{\circ}$, undepressed on admixture with decanoic acid, m.p. $31^{\circ}$. The bulk of the product was converted into the sodium salt by titration and evaporation to dryness, and this in turn was treated under reflux for $1 \mathrm{hr}$. with an equivalent of $p$-bromophenacyl bromide in ethanol $(10 \mathrm{ml}$.). On cooling and dilution with water the $p$-bromophenacyl ester separated and was crystallized from light petroleum, b.p. 40-60. This ester $\left(0.4 \mathrm{~g}\right.$.), m.p. $64-65^{\circ}$, produced no depression of m.p. on admixture with an authentic sample of decanoic acid $p$ bromophenacyl ester, m.p. $65^{\circ}$.

(b) With phosphoryl chloride. The degradation acid (1.0 g.), $\mathrm{POCl}_{3}(0.5 \mathrm{~g}$.) and benzene $(20 \mathrm{ml}$.) were heated under reflux for $2 \mathrm{hr}$. and the mixture stripped at the water pump at $100^{\circ}$. The residue was dissolved in ether and acidic matter separated by shaking, with $\mathrm{NaHCO}_{3}$ solution. Acidification of the alkaline extract precipitated oil $(0.3 \mathrm{~g}$.) which was isolated by ether extraction. This product, which was unsaturated $\left(\mathrm{Br}_{2}\right.$ in $\mathrm{CHCl}_{3}$ was decolorized) and also contained chlorine, was dissolved in methanol $(10 \mathrm{ml}$.) containing $\mathrm{NaOH}$ (10 drops of $2 \mathrm{~N}-$ ) and shaken with $\mathrm{Pd}-$ charcoal catalyst $\left(10 \%, w / w ; 0.05\right.$ g.) in $\mathrm{H}_{2}$ at room temp. and pressure. When $\mathrm{H}_{2}$ uptake ceased (40 ml. absorbed) the catalyst was removed and the solvent evaporated, leaving a residue smelling of decanoic acid. To this was added an excess of $\operatorname{SOCl}_{2}(1.0 \mathrm{ml}$.) and the mixture heated until evolution of $\mathrm{HCl}$ ceased, when excess of reagent was removed in vacuo at $100^{\circ}$. The crude acid chloride was dissolved in dry ether, and aniline $(1.0 \mathrm{ml}$.) was added and the mixture allowed to stand overnight, after which dilute $\mathrm{HCl}$ was added to remove excess of aniline from the ether phase, which was subsequently dried over anhydrous $\mathrm{Na}_{2} \mathrm{SO}_{4}$ and evaporated. The solid anilide separated from light petroleum (b.p $\left.40-60^{\circ}\right)$ in needles $\left(0.2\right.$ g.), m.p. $64-65^{\circ}$ (Found: C, 78.1; H, $10 \cdot 0 ; \mathrm{N}, 5 \cdot 2$. Calc. for $\mathrm{C}_{16} \mathrm{H}_{25} \mathrm{ON}: \mathrm{C}, 77 \cdot 8 ; \mathrm{H}, 10 \cdot 1 ; \mathrm{N}, 5 \cdot 7 \%$ ). This substance did not depress the m.p. of decanoic acid anilide, m.p. $66^{\circ}$. In the two experiments above, the neutral substance remaining in the original benzene layers was treated in the same way as the similar substance obtained by the action of hydrochloric acid on serratamic acid (see below) and shown to be identical with it.

Purification of D-3-hydroxydecanoic acid. Serratamic acid was hydrolysed by treatment with methanolic $\mathrm{HCl}$ as described by Cartwright (1955). The neutral ether-soluble product was fractionated at very low pressure, the bath being carefully maintained at the fixed temperature necessary to produce slow distillation. After three distillations methyl D-3-hydroxydecanoate, m.p. $13^{\circ}$, was obtained (Found: C, $65 \cdot 3 ; \mathrm{H}, 10 \cdot 8 . \mathrm{C}_{11} \mathrm{H}_{22} \mathrm{O}_{8}$ requires $\mathrm{C}, 65 \cdot 3 ; \mathrm{H}, 10 \cdot 9 \%$ ). Equal weights of the ester, acetic anhydride and fused sodium acetate were mixed and allowed to stand $18 \mathrm{hr}$. at room temp. Excess of acetic anhydride was removed at $40^{\circ}$ in vacuo and the product extracted in ether from the residue. Distillation gave $75 \%$ yields of methyl D-3-acetoxydecanoate, b.p. $72^{\circ} / 0.07 \mathrm{~mm}$. (Found: C, 63.5; H, 9.7. $\mathrm{C}_{13} \mathrm{H}_{24} \mathrm{O}_{4}$ requires $\mathrm{C}, 63 \cdot 8 ; \mathrm{H}, 9 \cdot 8 \%$ ).

Pure methyl D-3-hydroxydecanoate was hydrolysed in accordance with directions given by Cartwright (1955) for the less pure substance. The acidic product, D-3-hydroxydecanoic acid, was distilled twice in high vacuum, b.p. $115^{\circ}$ $0.002 \mathrm{~mm}$., m.p. $45-47^{\circ}$, and crystallized at $0^{\circ}$ from light petroleum (b.p. $40^{\circ}$ ) in needles, m.p. $47^{\circ},[\alpha]_{D}^{20}-19 \pm 1^{\circ}$ in $\mathrm{CHCl}_{3}(c, 2 \cdot 1$ ) (Found: $\mathrm{C}, 63 \cdot 8 ; \mathrm{H}, 10 \cdot 8 ; \mathrm{O}$ (direct) 25.5. $\mathrm{C}_{10} \mathrm{H}_{20} \mathrm{O}_{3}$ requires $\mathrm{C}, 63.8 ; \mathrm{H}, 10.7 ; 0,25.5 \%$ ).

The cinchonidine salt was prepared by dissolving the acid $(1.27 \mathrm{~g}$.) and cinchonidine $(2 \cdot 0 \mathrm{~g}$.) in boiling acetone $(50 \mathrm{ml}$.). On concentration to $25 \mathrm{ml}$. and cooling, the derivative (3.0 g.) separated as sheaves of needles, m.p. 119-120 $[\alpha]_{\mathrm{D}}^{20}-82 \cdot 7 \pm 0.5^{\circ}$ in $\mathrm{CHCl}_{3}(c, 2 \cdot 5)$. The rotation of this substance was unchanged by repeated crystallization from acetone, ethyl acetate or $\mathrm{CCl}_{4}$ (Found: $\mathrm{C}, 72.4 ; \mathrm{H}, 8.8 ; \mathrm{N}$, 5.7. $\mathrm{C}_{29} \mathrm{H}_{42} \mathrm{O}_{4} \mathrm{~N}_{2}$ requires $\mathrm{C}, 72 \cdot 2 ; \mathrm{H}, 8 \cdot 8 ; \mathrm{N}, 5 \cdot 8 \%$ ).

Resolution of DL-3-hydroxydecanoic acid. DL-3-Hydroxydecanoic acid $(1.0 \mathrm{~g}$.$) and cinchonidine (1.5 \mathrm{~g}$.) were dissolved in boiling $\mathrm{CCl}_{4}(50 \mathrm{ml}$.) and filtered to remove a small amount of undissolved substance. Concentration to $25 \mathrm{ml}$. and cooling produced a crop of crystals $(A, 1.5$ g. $)$, m.p. 90$100^{\circ}$. This obvious mixture was recrystallized six times from $\mathrm{CCl}_{4}$ and finally twice from ethyl acetate to give the cinchonidine salt of D-3-hydroxydecanoic acid (0.6 g.), m.p. 119-120,$[\alpha]_{\mathrm{D}}^{20}-82.5 \pm 0.5^{\circ}$ in $\mathrm{CHCl}_{3}(c, 2 \cdot 0)$ (Found: $\mathrm{C}$, $72.0 ; \mathrm{H}, 9 \cdot 0 ; \mathrm{N}, 5 \cdot 8 . \mathrm{C}_{29} \mathrm{H}_{42} \mathrm{O}_{4} \mathrm{~N}_{2}$ requires $\mathrm{C}, 72 \cdot 2 ; \mathrm{H}, 8 \cdot 8$; $\mathrm{N}, 5 \cdot 8 \%$ ). The mother liquors from crystals $A$ were gradually concentrated to produce five crops of impure crystals (which were combined with the mother liquors from the recrystallizations of substance $A$ in the normal manner of fractional crystallization) to leave a gummy substance $(0.7 \mathrm{~g}$.) from which crystals were not readily obtained. 
Liberation of the free acid from this crude salt and reconversion into the cinchonidine derivative in $\mathrm{CCl}_{4}$ gave a small quantity of relatively insoluble material which was discarded. Addition of light petroleum (b.p. 40-60 ${ }^{\circ}$ to the hot mother liquors gave a substance, m.p. 95-97 ${ }^{\circ}$, which after recrystallization from the same solvents gave the pure cinchonidine salt of L-3-hydroxydecanoic acid (0.5 g.), m.p. $98^{\circ},[\alpha]_{\mathrm{D}}^{20}-67 \pm 1^{\circ}$ in $\mathrm{CHCl}_{3}(c, 1 \cdot 3)$ (Found: $\mathrm{C}, 72 \cdot 0 ; \mathrm{H}, 8 \cdot 9$; $\mathrm{N}, 5 \cdot 6 \% \cdot \mathrm{C}_{29} \mathrm{H}_{48} \mathrm{O}_{4} \mathrm{~N}_{2}$ requires $\mathrm{C}, 72 \cdot 2 ; \mathrm{H}, 8 \cdot 8 ; \mathrm{N}, 5 \cdot 8 \%$ ). Prolonged manipulation of the fractions in the centre of the fractional crystallization diagram failed to yield any homogeneous crystals of either enantiomorph. Failure was likewise recorded with alternative solvents.

The optically active acids were recovered from the purified cinchonidine salts of m.p. $120^{\circ}$ and $98^{\circ}$ by suspension in ether and addition of dil. HCl. The ether solutions were washed with dil. $\mathrm{HCl}$ and water, dried over $\mathrm{Na}_{2} \mathrm{SO}_{4}$ and evaporated to give almost theoretical yields respectively of D-3-hydroxydecanoic acid, m.p. 46-47 (needles from light petroleum, b.p. $\left.40^{\circ}\right),[\alpha]_{\mathrm{D}}^{20}-17 \cdot 5 \pm 2^{\circ}$ in $\mathrm{CHCl}_{3}(c, 1 \cdot 0)$ (Found: $\mathrm{C}, 64 \cdot 0 ; \mathrm{H}, 10 \cdot 8 . \mathrm{C}_{10} \mathrm{H}_{20} \mathrm{O}_{3}$ requires $\mathrm{C}, 63.9 ; \mathrm{H}$, $10.6 \%$ ) (admixture with acid $\mathrm{C}_{10} \mathrm{H}_{20} \mathrm{O}_{3}$ from serratamic acid gave no depression of m.p.) and L-3-hydroxydecanoic acid, m.p. $45-47^{\circ}$ (needles from light petroleum, b.p. $40^{\circ}$ ), $[\alpha]_{\mathrm{D}}^{20}+18 \pm 2^{\circ}$ in $\mathrm{CHCl}_{3}(c, 1 \cdot 0)$ (Found: $\mathrm{C}, 63.9 ; \mathrm{H}, 10.8$. $\mathrm{C}_{10} \mathrm{H}_{20} \mathrm{O}_{3}$ requires $\mathrm{C}, 63.9 ; \mathrm{H}, 10.6 \%$ ). Admixture of this acid with a sample from Dr Serck-Hanssen produced no change in m.p., whereas admixture with an equal weight of the acid $\mathrm{C}_{10} \mathrm{H}_{20} \mathrm{O}_{3}$ from the degradation of serratamic acid raised the m.p. to $57^{\circ}$, which was unchanged by the addition of DL-3-hydroxydecanoic acid.

The p-bromophenacyl ester of D-3-hydroxydecanoic acid was prepared by standard procedures and it formed plates or needles, m.p. $105-106^{\circ}$ from light petroleum (b.p. $60-80^{\circ}$ ) (Found: $\mathrm{C}, 56 \cdot 2 ; \mathrm{H}, 6 \cdot 6 ; \mathrm{Br}, 20 \cdot 5 . \mathrm{C}_{18} \mathrm{H}_{25} \mathrm{O}_{4} \mathrm{Br}$ requires $\mathrm{C}$, $56 \cdot 1 ; \mathrm{H}, 6.5 ; \mathrm{Br}, 20 \cdot 8 \%$ ). No depression of m.p. was observed on admixture with the corresponding derivative of the acid $\mathrm{C}_{10} \mathrm{H}_{20} \mathrm{O}_{3}$ from the degradation of serratamic acid.

Action of hydrochloric acid on serratamic acid. Serratamic acid (5 g.) and conc. $\mathrm{HCl}(50 \mathrm{ml}$.) were heated on the water bath for $3 \mathrm{hr}$. and then cooled and diluted with water and the oil extracted into ether. Acidic material $(0 \cdot 2$ g.) was removed from the ether layer by extraction with saturated $\mathrm{NaHCO}_{3}$ solution, after which the ether solution was dried over $\mathrm{Na}_{8} \mathrm{SO}_{4}$, the solvent removed and the product distilled. After a small forerun of unsaturated material the cyclic ester (I) distilled (3 g.) with slight decomposition, b.p. $130 \%$ $0.001 \mathrm{~mm}$. (Found: $\mathrm{C}, 71 \cdot 0 ; \mathrm{H}, 10.8$. $\mathrm{C}_{20} \mathrm{H}_{36} \mathrm{O}_{4}$ requires $\mathrm{C}$, $70.6 ; \mathrm{H}, 10.6 \%)$. The foregoing ester $(1.0 \mathrm{~g}$.) dissolved on warming at $100^{\circ}$ with $2 \mathrm{~N}-\mathrm{NaOH}(25 \mathrm{ml}$.) and after $30 \mathrm{~min}$. the solution was cooled, acidified with dil. HCl and extracted with ether. After removal of the solvent the product was distilled $\left(0.7 \mathrm{~g} .\right.$, b.p. $115^{\circ} / 0.002 \mathrm{~mm}$.) and solidified. It had m.p. 43-45 , undepressed on admixture with the acid $\mathrm{C}_{10} \mathrm{H}_{20} \mathrm{O}_{3}$ described by Cartwright (1955).

By prolonged treatment of the acid $\mathrm{C}_{10} \mathrm{H}_{20} \mathrm{O}_{3}$ with hot conc. $\mathrm{HCl}$ the cyclic ester was produced and examined in the way described above. Neutral products from various acylation experiments submitted to similar procedures gave high yields of the acid $\mathrm{C}_{10} \mathrm{H}_{20} \mathrm{O}_{3}$.

Synthesis of racemic and optically active serratamic acid. DL-Serine ( $1.0 \mathrm{~g}$.) in methanol $(25 \mathrm{ml}$.) was saturated at room temp. with dry $\mathrm{HCl}$ and the solution refluxed for $3 \mathrm{hr}$. and then evaporated to dryness in a vacuum. It was re- dissolved in methanol and refluxed for a further period of $1 \mathrm{hr}$. and the solvent again removed in vacuo, the solid dissolved in water $(0.5 \mathrm{ml}$.), covered with ether $(25 \mathrm{ml}$.) and anhydrous $\mathrm{K}_{2} \mathrm{CO}_{3}(10 \mathrm{~g}$.) added in portions with shaking. The ethereal solution of DL-serine methyl ester was decanted and dried over anhydrous $\mathrm{K}_{2} \mathrm{CO}_{3}$ and used as described below.

DL-3-Hydroxydecanoic acid (1.5 g.) and pyridine (0.63 g.) in dry $\mathrm{CHCl}_{3}(25 \mathrm{ml}$.) was treated under reflux for $15 \mathrm{~min}$. with freshly distilled acetyl chloride $(0 \cdot 63 \mathrm{~g}$.) and the solvent removed at low temp. in vacuo. The product was dissolved in ether, washed with water and dried over anhydrous $\mathrm{Na}_{2} \mathrm{SO}_{4}$, and the solvent removed and replaced by $\mathrm{CHCl}_{3}(25 \mathrm{ml}$.); pure freshly distilled $\mathrm{SOCl}_{2}[9.6 \mathrm{ml}$. of a $10 \%(\mathrm{w} / \mathrm{v})$ solution in $\mathrm{CHCl}_{3}$ ] was added and the mixture refluxed for $0.5 \mathrm{hr}$. and the solvent then removed in vacuo. The product was dissolved in dry ether $(25 \mathrm{ml}$.) containing pyridine (0.75g.) and added to the ethereal solution of DL-serine methyl ester prepared above. After standing overnight the ethereal solution was decanted from the pyridine hydrochloride, washed with dil. $\mathrm{HCl}, \mathrm{NaHCO}_{3}$ solution and water, dried over $\mathrm{Na}_{2} \mathrm{SO}_{4}$ and evaporated. The residual oil was shaken for $24 \mathrm{hr}$. at room temp. with $\mathrm{N}-\mathrm{NaOH}(20 \mathrm{ml}$.), the resulting solution being acidified carefully with dil. $\mathrm{HCl}$. The addition of ether caused solidification of part of the oily product, which on filtration gave racemic serratamic acid or DL-N(3-hydroxydecanoyl)serine $\left(0.5\right.$ g.), m.p. 142-144 ${ }^{\circ}$ (Found, in purified product, m.p. $144^{\circ}$, from ethyl acetate: C, 57.1 ; $\mathrm{H}, 9 \cdot 3 ; \mathrm{N}, 4 \cdot 8 \%$; equiv. wt. 278. $\mathrm{C}_{13} \mathrm{H}_{25} \mathrm{O}_{5} \mathrm{~N}$ requires $\mathrm{C}$, $56 \cdot 8 ; \mathrm{H}, 9 \cdot 1 ; \mathrm{N}, 5 \cdot 1 \%$; equiv. wt. 275 ).

By exactly similar procedures serratamic acid was synthesized from $(a)$ the L-serine and D-3-hydroxydecanoic acid moieties obtained from hydrolysis of serratamic acid itself, and $(b)$ from commercial L-serine and D-3-hydroxydecanoic acid obtained in the resolution of DL-3-hydroxydecanoic acid described above. The product, N-(D-3-hydroxydecanoyl) L-serine, crystallized from ethyl acetate or water in needles, m.p. $136-137^{\circ}$, undepressed on admixture with natural serratamic acid, m.p. 137-138 ${ }^{\circ}$ (Found: C, 57.0; H, 9.4; $\mathrm{N}, 4.9 \%$; equiv. wt. 275 . $\mathrm{C}_{13} \mathrm{H}_{25} \mathrm{O}_{5} \mathrm{~N}$ requires $\mathrm{C}, 56.8 ; \mathrm{H}$, $9 \cdot 3 ; \mathrm{N}, 5 \cdot 1 \%$; equiv. wt. 275$)$.

Chloroserratamic acid methyl ester. The non-volatile residue which was insoluble in $\mathrm{NaHCO}_{3}$ solution from the hydrolysis of serratamic acid $(2.0 \mathrm{~g}$.) by methanol-HCl (Cartwright, 1955) solidified and crystallized from light petroleum (b.p. $\left.60-80^{\circ}\right)$ in needles $\left(0 \cdot 2\right.$ g.), m.p. $91^{\circ}$. (Found: $\mathrm{C}, 54 \cdot 9 ; \mathrm{H}, 8 \cdot 7 ; \mathrm{Cl}, 11 \cdot 5 ; \mathrm{N}, 4 \cdot 7 . \mathrm{C}_{14} \mathrm{H}_{26} \mathrm{O}_{4} \mathrm{NCl}$ requires $\mathrm{C}$, $54 \cdot 6$; H, 8.5; Cl, $11.5 ; \mathrm{N}, 4 \cdot 6 \%$ ).

Deoxyserratamic acid methyl ester. The foregoing chloro compound ( $0.2 \mathrm{~g}$.) was dissolved in methanol $(5 \mathrm{ml}$.$) and$ shaken in an atmosphere of $\mathrm{H}_{2}$ in the presence of $\mathrm{Pd}-$ charcoal catalyst $(10 \%, w / w, 0.05 \mathrm{~g}$.) and $2 \mathrm{~N}-\mathrm{NaOH}$ $(0.3 \mathrm{ml}$.). In $10 \mathrm{~min}$. $14 \mathrm{ml}$. of gas was absorbed (approx. theoretical) and the catalyst was removed, the solution diluted with water and the product extracted into ether. After shaking with $\mathrm{NaHCO}_{3}$ solution the ether solution was dried and evaporated, leaving a residue $(0 \cdot 1 \mathrm{~g}$.) which crystallized from light petroleum (b.p. 40-60 $0^{\circ}$ in rosettes of needles, m.p. 57-58 (Found: C, 61.3; H, 10.3; N, 4.8. $\mathrm{C}_{14} \mathrm{H}_{27} \mathrm{O}_{4} \mathrm{~N}$ requires $\mathrm{C}, 61.5 ; \mathrm{H}, 10 \cdot 0 ; \mathrm{N}, 5 \cdot 1 \%$ ).

$\mathrm{Hydrolysis} \mathrm{was} \mathrm{effected} \mathrm{by} \mathrm{heating} \mathrm{on} \mathrm{the} \mathrm{water} \mathrm{bath} \mathrm{with}$ conc. HCl (2.0 ml.) for $30 \mathrm{~min}$. After dilution with water and shaking with ether the aqueous layer was separated and concentrated in vacuo. A portion of the product thus 
obtained was applied to a paper along with L-serine and authentic $\alpha$-alanine and the chromatogram run in $80 \%$ phenol. Development with ninhydrin showed the product to have the same $R_{F}$ value as $\alpha$-alanine.

2:3-E poxydecanoic acid. Freshly distilled octyl aldehyde (5.7 g.) and ethyl chloroacetate (5.5 g.) in dry ether (100 ml.) were added to sodium methoxide (from $1.0 \mathrm{~g}$. of $\mathrm{Na}$ ) suspended in dry ether. After standing for $48 \mathrm{hr}$. at room temp. water was added, and the ether layer was separated and dried over anhydrous $\mathrm{Na}_{2} \mathrm{SO}_{4}$. The oil left after removal of the solvent was purified by vacuum distillation, yielding ethyl 2:3-epoxydecanoate (6 g., b.p. $90-93^{\circ} / 0 \cdot 1 \mathrm{~mm}$.). Saponification rapidly occurred on the addition of an excess of $12 \%(w / v) \mathrm{KOH}$ in methanol at room temp., with the precipitation of a potassium salt. The mixture was left overnight, diluted with water and carefully acidified with dil. $\mathrm{HCl}$, when the 2:3-epoxydecanoic acid separated as an oil which solidified on standing and was crystallized from light petroleum (b.p. $40-60^{\circ}$ ) in plates, m.p. $59^{\circ}$ (Found: $\mathrm{C}$, $64 \cdot 6$; $\mathrm{H}, 9.5 \%$; equiv. wt. $184 . \mathrm{C}_{10} \mathrm{H}_{18} \mathrm{O}_{3}$ requires $\mathrm{C}, 64 \cdot 5$; $\mathrm{H}, 9 \cdot 7 \%$; equiv. wt. 186). This substance depressed the m.p. of 3-hydroxydecanoic acid, which could possibly have also arisen in the condensation. A solution of the acid in saturated $\mathrm{NaHCO}_{3}$ solution precipitated a sodium salt on standing, and this behaviour was not observed under similar conditions with 3-hydroxydecanoic acid.

Fission of the epoxide ring and regeneration of 2:3-epoxydecanoic acid. (1) The acid (0.5 g.) was dissolved in conc. $\mathrm{HCl}(20 \mathrm{ml}$.) and the mixture heated with frequent shaking on a water bath for $30 \mathrm{~min}$. After dilution with water and extraction with ether, acidic material was removed from the organic phase by saturated $\mathrm{NaHCO}_{3}$ solution. Acidification of the alkaline layer with dil. $\mathrm{HCl}$ yielded chlorohydroxydecanoic acid (0.3 g.), which crystallized from light petroleum (b.p. $40-60^{\circ}$ ) in needles, m.p. 93 (Found: C, 53.9; H, 8.7; $\mathrm{Cl}$, 15.6. $\mathrm{C}_{10} \mathrm{H}_{19} \mathrm{O}_{3} \mathrm{Cl}$ requires $\mathrm{C}, 54 \cdot 0 ; \mathrm{H}, 8 \cdot 6 ; \mathrm{Cl}, 15 \cdot 9 \%$ ).

(2) The chloro acid $(0.2 \mathrm{~g}$.) was added to a solution of $\mathrm{KOH}$ in methanol $(20 \%, \mathrm{w} / \mathrm{v} ; 2 \mathrm{ml}$.). Solid rapidly separated from the mixture, which was stored at room temp. for $2 \mathrm{hr}$. After dilution with water and acidification the product was separated in ether and crystallized from light petroleum (b.p. $\left.40-60^{\circ}\right)$ in plates, $(0 \cdot 15$ g.), m.p. 58-59 , undepressed on admixture with 2:3-epoxydecanoic acid prepared above.
Derivatives of 2-hydroxy-2-methylnonanoic acid. $p$-Nitrobenzoyl chloride $(0 \cdot 1 \mathrm{~g}$.) was added to 2 -hydroxy-2-methylnonanoic acid $(0 \cdot 1 \mathrm{~g}$.$) in dry pyridine (2 \mathrm{ml}$.) and the mixture kept at $56^{\circ}$ for $18 \mathrm{hr}$. To the cooled solution dil. $\mathrm{HCl}$ was added until the odour of pyridine was no longer apparent, and the solid material was filtered off, washed with $\mathrm{NaHCO}_{3}$ solution and water, dried and crystallized from light petroleum (b.p. 80-100 ${ }^{\circ}$ ). 2-Methyl-2-p-nitrobenzoyloxynonanoic acid ( $0.15 \mathrm{~g}$.) separated in cream-coloured needles, m.p. $137^{\circ}$ (Found: $\mathrm{C}, 60 \cdot 5 ; \mathrm{H}, 7 \cdot 0 ; \mathrm{N}, 4 \cdot 0 . \mathrm{C}_{17} \mathrm{H}_{23} \mathrm{O}_{6} \mathrm{~N}$ requires $\mathrm{C}, 60.5 ; \mathrm{H}, 6.9 ; \mathrm{N}, 4.2 \%$ ). The p-bromophenacyl ester of 2-hydroxy-2-methylnonanoic acid was prepared in $80 \%$ yield by refluxing for $1 \mathrm{hr}$. equimolecular quantities of the sodium salt and $p$-bromophenacyl bromide in ethanol. It formed felted needles, m.p. $111^{\circ}$, from light petroleum. (Found: $\mathrm{C}, 56 \cdot 2 ; \mathrm{H}, 6 \cdot 5 ; \mathrm{Br}, 20 \cdot 7$. $\mathrm{C}_{18} \mathrm{H}_{25} \mathrm{O}_{4} \mathrm{Br}$ requires: $\mathrm{C}$, $56 \cdot 1 ; \mathrm{H}, 6 \cdot 5 ; \mathrm{Br}, 20 \cdot 8 \%$ ).

\section{SUMMARY}

1. The acid, $\mathrm{C}_{10} \mathrm{H}_{20} \mathrm{O}_{3}$, from hydrolysis of serratamic acid has been equated with D-3-hydroxydecanoic acid.

2. Racemic serratamic acid and serratamic acid have been synthesized and shown to be the optically inactive and active forms respectively of $N$-(3hydroxydecanoyl)serine.

3. DL-3-Hydroxydecanoic acid has been resolved by fractional crystallization of cinchonidine salts.

4. 2:3-Epoxydecanoic acid has been synthesized.

5. The infrared spectra of serratamic acid and several oxygenated decanoic acids have been recorded.

\section{REFERENCES}

Bergström, S., Theorell, H. \& Davide, H. (1946). Arch. Biochem. 10, 165.

Cartwright, N. J. (1955). Biochem. J. 60, 238.

Maehlmann, H. (1915). Chem. Zbl. 11, 1178.

Sakami, W. \& Toennies, G. (1942). J. biol. Chem. 144, 203.

Serck-Hanssen, K. (1956). Arkiv. Kemi, 10, 135.

Serck-Hanssen, K. \& Stenhagen, E. (1955). Acta chem. scand. 9, 866 .

\title{
Synthesis of Cellulose by Acetobacter xylinum
}

\section{SUBSTRATES AND INHIBITORS*}

\author{
BY M. SCHRAMM, Z. GROMET AND SHLOMO HESTRIN \\ Laboratory of Microbiological Chemistry of the Department of Biochemistry, \\ Hebrew University-Hadassah Medical School, Jerusalem, Israel
}

\section{(Received 12 April 1957)}

Earlier communications described a microassay of cellulose (Schramm \& Hestrin, 1954 $a$ ) and the preparation of Acetobacter xylinum as a fibril-free, stable suspension of washed non-proliferating cells

* Part 2: Hestrin \& Schramm (1954). For a preliminary communication on some experiments described in the present paper and results obtained in a tracer analysis of cellulose production, see Schramm, Gromet \& Hestrin (1957). of high cellulose-synthesizing potency (Hestrin \& Schramm, 1954). It was hoped that with the aid of these tools an effective approach could be made to unsolved problems in the chemistry and mechanics of cellulose production, and indeed that it might not be difficult to effect a separation of the cellulosesynthesizing enzyme system from the structure of the cell. However, this hope has not been fulfilled. 